\title{
ANALISIS PERCEPATAN WAKTU PENYELESAIAN PROYEK MENGGUNAKAN METODE FAST-TRACK DAN CRASH PROGRAM
}

\author{
Analysis Of Acceleration Time Of Project Solving Using Fast-Track And Crash \\ Program Method \\ Yohanes Stefanus ${ }^{1}$, Indradi Wijatmiko ${ }^{2}$, Eko Andi Suryo ${ }^{3}$ \\ 1,2,3 Jurusan Teknik Sipil, Universitas Brawijaya \\ Jl. MT. Haryono No 167 Malang, 65145, Jawa Timur \\ Alamat Korespondensi : \\ Email: stefanustjung@gmail.com
}

\begin{abstract}
The purpose of this study was to determine the acceleration time and cost-saving project Phase II Hotel Dewarna Bojonegoro. Based on the report on the realization until week 13 or 86 working days reached $34.58 \%$ while the percentage of initial plan of $53.522 \%$, resulting in a deviation between planned and realized. As a result, work has been delayed time originally planned to be completed within 233 days to 261 days. To accelerate project completion time in order to avoid delays in the assessment of this method and the fast-track and crash program and then compared the results. The results of the analysis using the fast-track and crash program in terms of time can be emphasized again as the original plan that the project is completed within 233 days. In terms of cost with fast-track method requires a fee of $R p$ $26,376,440,619$, while the method of crash program requires a fee of $R p 26,504,146,817$. Both methods are able to reduce costs due to project delays, initially amounting to $R p$ 27,059,140,712. in terms of the cost of a fast-track method is cheaper, but have a greater risk because if one of the jobs that are on the critical path is delayed will affect other jobs.
\end{abstract}

Keywords : Cost, Crash program, Fast-track, Time

\begin{abstract}
Abstrak
Tujuan penelitian ini adalah untuk mengetahui percepatan waktu dan biaya yang dapat dihemat pada proyek Hotel Dewarna Tahap II Bojonegoro. Berdasarkan laporan realisasi sampai minggu ke-13 atau 86 hari kerja baru mencapai 34,58\% sedangkan persentase rencana awal sebesar 53,522\%, sehingga terjadi deviasi antara rencana dan realisasi. Akibatnya pekerjaan mengalami keterlambatan waktu yang awalnya direncanakan selesai dalam waktu 233 hari menjadi 261 hari. Untuk mempercepat waktu penyelesaian proyek agar tidak terjadi keterlambatan maka kajian ini menggunakan metode fast-track dan crash program untuk kemudian dibandingkan hasilnya. Hasil analisis menggunakan metode fast-track dan crash program dari segi waktu bisa ditekankan kembali seperti rencana awal yaitu proyek selesai dalam waktu 233 hari. Dari segi biaya dengan metode fast-track membutuhkan biaya sebesar Rp 26.376.440.619, sedangkan dengan metode crash program membutuhkan biaya sebesar Rp 26.504.146.817. Kedua metode tersebut mampu mengurangi biaya akibat keterlambatan proyek yang awalnya sebesar Rp 27.059.140.712. dari segi biaya metode fast-track lebih murah, akan tetapi memiliki resiko yang lebih besar karena apabila salah satu pekerjaan yang berada pada lintasan kritis mengalami keterlambatan akan mempengaruhi pekerjaan lainnya.
\end{abstract}

Kata kunci : Biaya, Crash program, Fast-track, Waktu

\section{PENDAHULUAN}

Dalam suatu proyek konstruksi, kontraktor merupakan pihak yang bertanggungjawab untuk menyelesaikan proyek tersebut dengan mutu, durasi, serta biaya sesuai dengan yang direncanakan. Oleh karena itu, pihak kontraktor akan menyusun suatu penjadwalan proyek sebelum memulai proyek konstruksi. Meskipun penjadwalan telah disusun, namun pada kenyataannya di lapangan masih sering terjadi keterlambatan 
penyelesaian proyek. Berdasarkan pada permasalahan di atas, tentunya pihak kontraktor akan semakin dituntut untuk dapat mengendalikan penjadwalan proyeknya sehingga mengurangi risiko keterlambatan proyek. Pada umumnya kontraktor menggunakan metode penjadwalan yang bisa mengurangi waktu penyelesaian proyek menjadi lebih cepat dan juga biaya penyelesaian proyek dengan biaya yang lebih rendah. Pada saat dilakukan penelitian, dari hasil laporan kemajuan pekerjaan hingga minggu ke-13 Proyek Hotel Dewarna Tahap II Bojonegoro sebesar 34,58\% dari rencana awal yang seharusnya pada minggu ke-13 sebesar $53,522 \%$. Dengan adanya keterlambatan pada Proyek Hotel Dewarna Tahap II Bojonegoro, maka penelitian ini akan mengevaluasi tentang pengendalian waktu dan biaya untuk mendapatkan optimalisasi kinerja waktu dan biaya.

Dari uraian latar belakang diatas, rumusan masalah yang akan dibahas dalam penelitian ini adalah bagaimana percepatan waktu dan biaya yang dapat dihemat pada Proyek Hotel Dewarna Tahap II Bojonegoro dengan menggunakan metode fast-track dan crash program. Sedangkan tujuan dari penelitian ini adalah untuk mengetahui percepatan waktu dan biaya yang dapat dihemat pada Proyek Hotel Dewarna Tahap II Bojonegoro dengan menggunakan metode fasttrack dan crash program.

\section{METODE PENELITIAN}

Dalam penelitian ini dilakukan analisis fast track dan crash program dengan langkahlangkah sebagai berikut:

\section{Metode Fast-Track :}

- Mengumpulkan data-data proyek seperti ; rencana anggaran biaya (RAB), kurva $S$, harga satuan pekerjaan, harga satuan bahan standar, analisa harga satuan, yang sudah direncanakan pada saat penawaran, laporan kemajuan fisik pekerjaan proyek setiap minggunya yang merupakan hasil pantauan dari konsultan pengawas selama pelaksanaan proyek berlangsung.

- Membuat urutan aktivitas dan hubungan yang logis antara aktivitas yang ada dan cukup realistis untuk dilaksanakan.

- Menentukan lintasan kritis dengan bantuan program Microsoft Project.

- Setelah diketahui aktivitas-aktivitas di lintasan kritis dengan program Microsoft
Project, selanjutnya dilakukan penjadwalan fast-track pada aktivitasaktivitas di lintasan kritis dengan menerapkan ketetntuan/prinsip fast-track.

- Kemudian menentukan waktu yang akan dipercepat dan melakukan percepatan yang diinginkan untuk mempercepat waktu pelaksanaan.

- Setelah mendapatkan waktu yang dipercepat, kemudian melakukan perbandingan biaya awal dengan biaya setelah fast-track.

\section{Metode Crash program :}

- Mengumpulkan data-data proyek seperti ; rencana anggaran biaya (RAB), kurva $S$, harga satuan pekerjaan, harga satuan bahan standar, analisa harga satuan, yang sudah direncanakan pada saat penawaran, laporan kemajuan fisik pekerjaan proyek setiap minggunya.

- Membuat urutan aktivitas dan hubungan yang logis antara aktivitas yang ada dan cukup realistis untuk dilaksanakan.

- Menentukan lintasan kritis dengan bantuan program Microsoft Project.

- Setelah diketahui aktivitas-aktivitas di lintasan kritis dengan program Microsoft Project, selanjutnya dilakukan analisis percepatan waktu pada aktivitas-aktivitas di lintasan kritis.

- Menghitung biaya crash cost dari setiap aktivitas-aktivitas di lintasan kritis. Kemudian

- Menghitung nilai slope masing- masing kegiatan

Cost Slope $=\frac{\text { crash cost }- \text { normal cost }}{\text { normal duration }- \text { crash duration }}$

- Menghitung total cost normal dan total cost setelah crash program. 


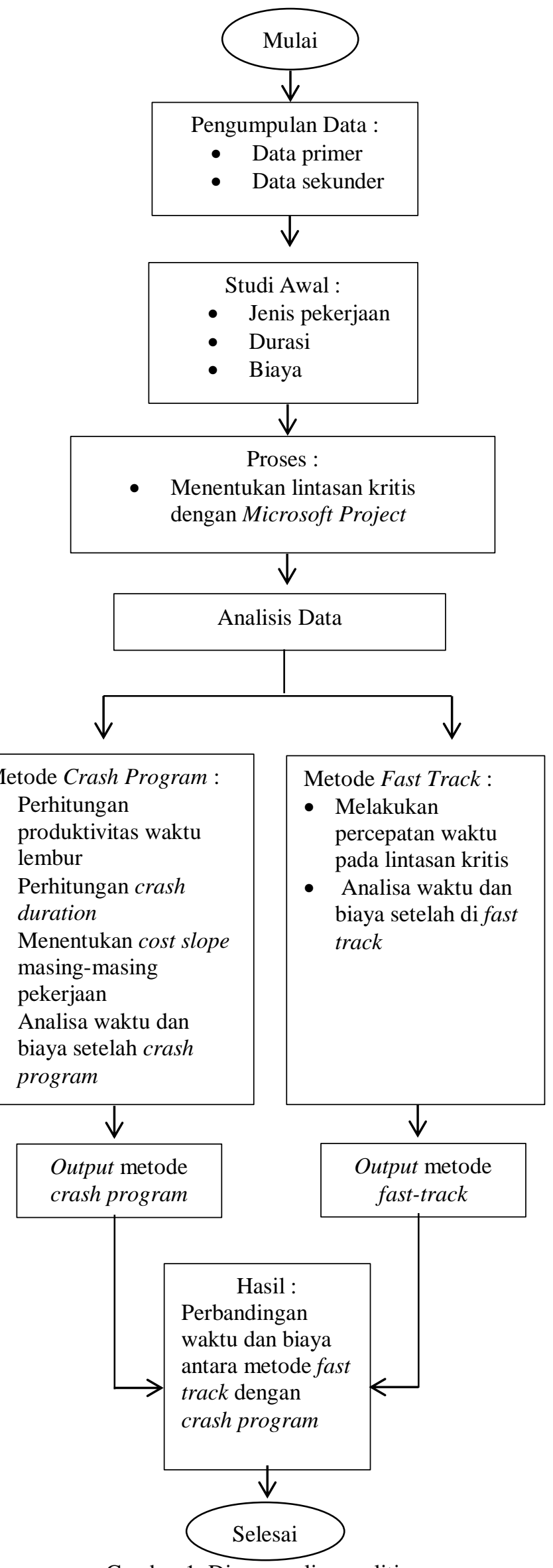

Metode Crash Program :

- Perhitungan produktivitas waktu lembur

- Perhitungan crash duration

- Menentukan cost slope masing-masing pekerjaan

- Analisa waktu dan biaya setelah crash program

Gambar 1. Diagram alir penelitian

\section{HASIL DAN PEMBAHASAN \\ Deskripsi Data}

Proyek yang ditinjau dalam penelitian ini adalah proyek Pembangunan Hotel Dewarna Tahap II Bojonegoro, dengan nilai kontrak Rp. 23.025.400.563 dan waktu pelaksanaan selama 233 hari kalender, dengan rincian tanggal pekerjaan dimulai pada 24 Oktober 2015 dan berakhir pada tanggal 17 Juni 2016. Data laporan kemajuan fisik dari pihak konsultan pengawas menunjukkan bahwa pelaksanaan kegiatan sampai minggu ke-13 atau 86 hari kalender baru mencapai $34,58 \%$ sedangkan persentasi rencana $53,522 \%$, sehingga terjadi deviasi antara rencana dan realisasi adalah $18,942 \%$ akibatnya pekerjaan yang awalnya direncanakan selesai dengan waktu 233 hari menjadi 261 hari atau terlambat 28 hari kerja (gambar 2). Adapun pekerjaan yang berada pada lintasan kritis yaitu : pekerjaan pasangan dan pekerjaan pengecatan di gedung B (gambar 2). Oleh karena itu, dalam penelitian ini akan mencoba melakukan percepatan waktu pada pekerjaan yang berada di lintasan kritis dengan metode fast-track dan crash program untuk kemudian dibandingkan hasilnya.

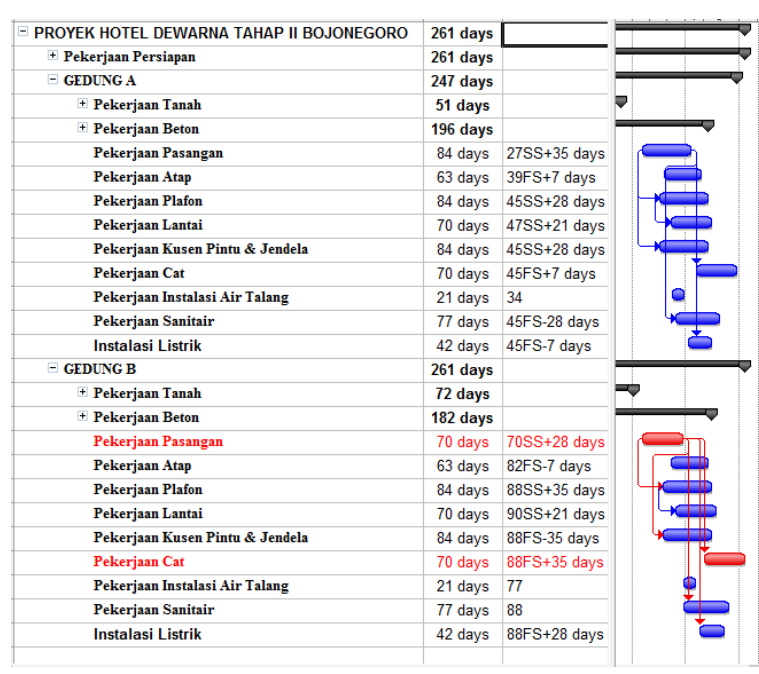

Gambar 2. Penjadwalan sebelum fast-track

\section{Analisis Metode Fast-Track}

Analisis perhitungan metode fast-track tidak ada penambahan jumlah tenaga kerja dan biaya pada masing-masing pekerjaan, demikian pula dengan penggunaan bahan yang sesuai dengan penggunaan normal. Dalam menganalisis percepatan waktu yang dilakukan pada minggu ke-13 waktu penyelesaian proyek gedung A 247 hari, sedangkan gedung B 261 hari. Adapun pekerjaan yang berada pada lintasan 
kritis yaitu : pekerjaan pasangan dan pekerjaan pengecatan gedung B. Pekerjaan pasangan tidak dilakukan fast-track karena pekerjaan kritis sebelumnya yaitu pekerjaan balok sudah dikerjakan sehingga pekerjaan pasangan tidak mungkin dimajukan lagi pekerjaannya. Jadi pekerjaan yang dilakukan fast-track hanya pekerjaan pengecatan gedung B. Pekerjaan pengecatan gedung B yang awalnya mempunyai hubungan dengan pekerjaan sebelumnya yaitu pekerjaan pasangan $\mathrm{FS}+35$ hari dirubah menjadi FS+7 hari sehingga waktu penyelesaian gedung B menjadi 233 hari (gambar 3).



Gambar 3. Penjadwalan setelah fast-track I

Setelah pekerjaan pengecatan di gedung B di fast-track pekerjaan pasangan dan pekerjaan pengecatan gedung A menjadi kritis sehingga harus dilakukan fast-track. Disini pekerjaan pasangan tidak dilakukan fast-track alasannya seperti pada gedung B. Jadi hanya pekerjaan pengecatan yang di fast-track. Awalnya pekerjaan pengecatan mempunyai hubungan dengan pasangan bata FS +7 hari, kemudian dengan fast-track hubungannya dirubah menjadi FS-7 hari sehingga waktu penyelesaian gedung A menjadi 233 hari. Setelah dilakukan fast-track pada gedung A dan B muncul lintasan kritis baru di pekerjaan sanitair, namun dalam hal ini pekerjaan sanitair tidak dilakukan fast-track karena waktu penyelesaian proyek menggunakan fast-track pada pekerjaan pengecatan sebelumnya sudah sesuai jadwal rencana awal yaitu 233 hari. (gambar 4).

Biaya proyek secara keseluruhan untuk penyelesaian sisa pekerjaan sebelum fast-track dengan waktu 261 hari sebesar Rp 27.059.140.712, sedangkan dengan menggunakan metode fast-track waktu penyelesaian proyek menjadi 233 hari seperti rencana awal yaitu 233 hari dengan biaya pelaksanaan proyek Rp 26.376.440.619.

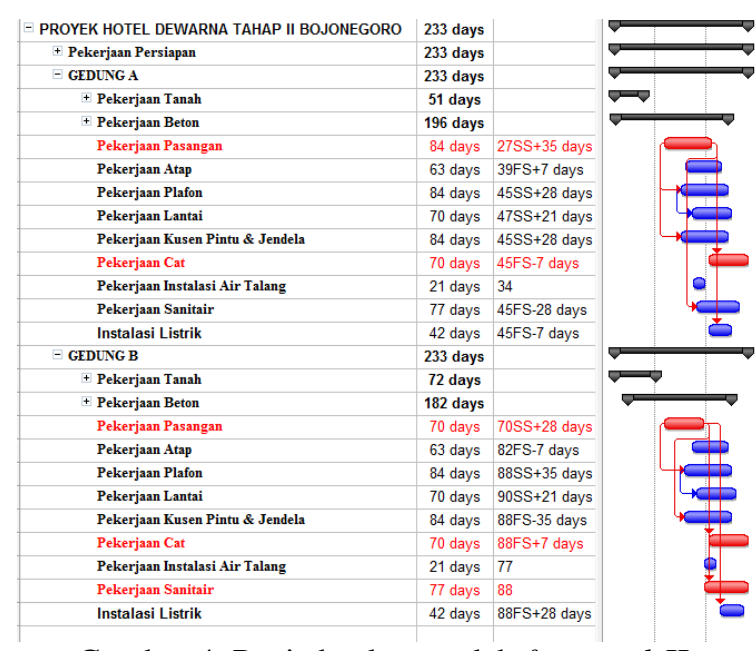

Gambar 4. Penjadwalan setelah fast-track II

\section{Analisis Metode Crash Program}

Crash program adalah salah satu cara untuk mempercepat waktu penyelesaian proyek, yaitu dengan mereduksi waktu penyelesaian kegiatan yang berada di lintasan kritis yang akan berpengaruh terhadap waktu penyelesaian proyek. Adapun pekerjaan yang berada pada lintasan kritis yaitu pekerjaan pasangan dan pengecatan di gedung B. Percepatan penyelesaian Proyek Hotel Dewarna Tahap II Bojonegoro ini dilakukan dengan menggunakan jam lembur.

Rencana kerja yang akan dilakukan dalam mempercepat waktu penyelesaian sebuah kegiatan dengan metode jam lembur adalah sebagai berikut :

- Kegiatan normal menggunakan 8 jam kerja dan 1 jam istirahat (08.00-17.00 WIB), sedangkan kerja lembur dilakukan setelah waktu kerja normal selama 4 jam perhari (18.00-22.00 WIB). Tenaga kerja yang lembur sama dengan tenaga kerja yang reguler.

- Harga upah pekerja umtuk kerja lembur diperhitungkan 2 kali upah sejam pada waktu kerja normal.

- Produktivitas untuk kerja lembur diperhitungkan sebesar $60 \%$ dari produktivitas normal. Penurunan produktivitas ini disebabkan karena faktor kelelahan, keterbatasan pandangan pada malam hari dan kondisi cuaca yang lebih dingin. 


\section{Menghitung Percepatan Waktu Penyelesaian Sisa Pekerjaan di Gedung B}

Perhitungan percepatan waktu penyelesaian proyek dilakukan pada pekerjaan yang ada di lintasan kritis yaitu pekerjaan pasangan dan pekerjaan pengecatan.

A. Pekerjaan pasangan :

$$
\begin{aligned}
& \text { produktivitas harian }=\frac{\text { bobot pekejaan }}{\text { rencana durasi }} \\
& \text { produktivitas harian }=\frac{6,49}{70}=0,0927 \\
& \text { produktivitas perjam }=\frac{\text { produktivitas harian }}{8 \text { jam }} \\
& \text { produktivitas perjam }=\frac{0,0927}{8}=0,011
\end{aligned}
$$

Selanjutnya waktu penyelesaian kegiatan setelah dilakukan crash :

Produktivitas harian setelah crash

$=(8 \times 0,011)+(4 \times 0,6 \times 0,011)=0,1205$

Waktu penyelesaian $=\frac{6,49}{0,1205}=53,84$ hari

Jadi waktu yang dibutuhkan untuk menyelesaikan pekerjaan pasangan setelah dilakukan crash adalah 53,84 hari, sehingga waktu yang dipercepat 16,16 hari.

\begin{tabular}{ccc}
\multicolumn{3}{c}{ Tabel 1. Percepatan waktu gedung B } \\
\hline No & $\begin{array}{c}\text { Jenis } \\
\text { Pekerjaan }\end{array}$ & $\begin{array}{c}\text { Waktu yang } \\
\text { dipercepat (hari) }\end{array}$ \\
\hline 1 & Pasangan & $70-53,84=16,16$ \\
2 & Pengecatan & $70-53,84=16,16$ \\
\hline
\end{tabular}

\section{Perhitungan Crash Cost Pekerja Gedung B}

Akibat percepatan waktu penyelesaian kegiatan terjadi peningkatan biaya dalam hal pembayaran upah pekerja atau dikenal dengan istilah crash cost pekerja. Secara garis besar perhitungan dilakukan sebagai berikut :

A. Pekerjaan pasangan :

$>$ Menghitung upah kerja perhari normal

$$
\begin{aligned}
& =\frac{\text { harga total upah kerja }}{\text { waktu penyelesaian kegiatan normal }} \\
& =\frac{\operatorname{Rp} 256.937 .816}{70}=\mathrm{Rp} 3.670 .540 .
\end{aligned}
$$

$>$ Menghitung upah kerja perjam normal

$=\frac{\text { upah kerja perhari normal }}{8}$

$=\frac{\operatorname{Rp} 3.670 .450}{8}=\operatorname{Rp} 458.818$.
Menghitung upah kerja lembur untuk 1 hari

$=4$ ( $2 \times$ upah sejam normal $)$

$=4(2 \times \operatorname{Rp} 458.818)$

$=\mathrm{Rp} 3.670 .450$.

$>$ Menghitung upah crash cost pekerja perhari

$=(8 \times$ upah kerja perjam normal $)+$ upah

kerja lembur

$=(8 \times R p 458.818)+R p 3.670 .450=R p$

7.341 .080

$>$ Menghitung crash cost total

= crash cost pekerja perhari $\times$ crash

duration

$=$ Rp7.341.080 x 53,84 hari

$=\operatorname{Rp} 395.288 .947$.

Tabel 2 Total crash cost pekerja

\begin{tabular}{cll}
\hline No & $\begin{array}{c}\text { Jenis } \\
\text { Pekerjaan }\end{array}$ & Crash cost total \\
\hline 1 & Pasangan & Rp 395.288.947 \\
2 & Pengecatan & Rp 44.080 .224 \\
\hline
\end{tabular}

Setelah menghitung crash cost maka selanjutnya menghitung cost slope dari masingmasing pekerjaan.

Tabel 3 Cost slope

\begin{tabular}{ccc}
\hline No & Jenis Pekerjaan & Cost Slope \\
\hline 1 & Pasangan & $\mathrm{Rp} 8.564 .594$ \\
2 & Pengecatan & $\mathrm{Rp} 955.072$ \\
\hline
\end{tabular}

Berdasarkan tabel 3 pekerjaan pengecatan mempunyai nilai cost slope terkecil sehingga pekerjaan pengecatan yang akan dilakukan crash.

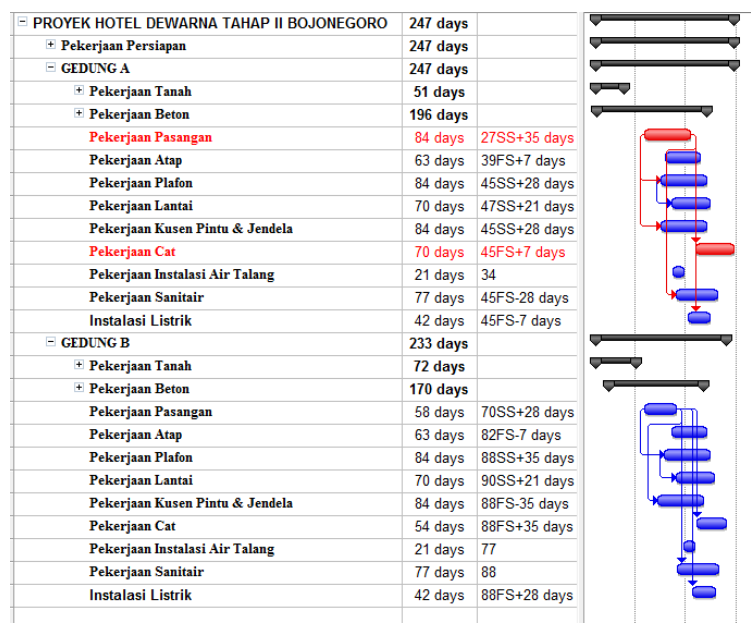

Gambar 5. Penjadwalan setelah crash I 




Selanjutnya waktu penyelesaian kegiatan setelah dilakukan crash:

Produktivitas harian setelah crash

$=(8 \times 0,0076)+(4 \times 0,6 \times 0,0076)=0,0792$

Waktu penyelesaian $=\frac{5,12}{0,0792}=64,61$ hari

Jadi waktu yang dibutuhkan untuk menyelesaikan pekerjaan pasangan setelah dilakukan crash adalah 64,61 hari, sehingga waktu yang dipercepat 19,39 hari.

Tabel 4 Percepatan waktu gedung A

\begin{tabular}{ccc}
\hline No & $\begin{array}{c}\text { Jenis } \\
\text { Pekerjaan }\end{array}$ & $\begin{array}{c}\text { Waktu yang } \\
\text { dipercepat (hari) }\end{array}$ \\
\hline 1 & Pasangan & $84-64,61=19,39$ \\
2 & Pengecatan & $70-53,84=16,16$ \\
\hline
\end{tabular}

\section{Perhitungan Crash Cost Pekerja Gedung A}

Akibat percepatan waktu penyelesaian kegiatan terjadi peningkatan biaya dalam hal pembayaran upah pekerja atau dikenal dengan istilah crash cost pekerja. Secara garis besar perhitungan dilakukan sebagai berikut :

B. Pekerjaan pasangan :

$>$ Menghitung upah kerja perhari normal

$$
\begin{aligned}
& =\frac{\text { harga totalupah kerja }}{\text { waktu penyelesaian kegiatan normal }} \\
& =\frac{\text { Rp180.315.00 }}{84}=\mathrm{Rp} 2.146 .607 .
\end{aligned}
$$

$>$ Menghitung upah kerja perjam normal $=\frac{\text { upah kerja perhari normal }}{8}$

$=\frac{\operatorname{Rp} 2.146 .607}{8}=\operatorname{Rp} 268.326$.
$>$ Menghitung upah kerja lembur untuk 1 hari

$=4$ ( 2 x upah sejam normal $)$

$=4(2 \times \operatorname{Rp} 268.326)=\operatorname{Rp} 2.146 .607$

$>$ Menghitung upah crash cost pekerja perhari

$=(8 \times$ upah kerja perjam normal $)+$ upah kerja lembur

$=(8 \times \operatorname{Rp} 268.326)+\mathrm{Rp} 2.146 .607$

$=\mathrm{Rp} 4.293 .214$

$>$ Menghitung crash cost total

$=$ crash cost pekerja perhari $\times$ crash duration

$=\operatorname{Rp} 4.293 .214 \times 64,61$ hari

$=\operatorname{Rp} 277.407 .692$

Tabel 5 Total crash cost pekerja

\begin{tabular}{ccc}
\hline No & $\begin{array}{c}\text { Jenis } \\
\text { Pekerjaan }\end{array}$ & Crash cost total \\
\hline 1 & Pasangan & Rp 277.407.692 \\
2 & Pengecatan & Rp 31.834 .512 \\
\hline
\end{tabular}

(Sumber : Hasil Analisis)

Setelah menghitung crash cost maka selanjutnya menghitung cost slope dari masingmasing pekerjaan.

Tabel 6 Cost slope

\begin{tabular}{lll}
\hline No & Jenis Pekerjaan & \multicolumn{2}{c}{ Cost Slope } \\
\hline 1 & Pasangan & $\mathrm{Rp} \mathrm{5.008.750}$ \\
2 & Pengecatan & $\mathrm{Rp} \quad 689.748$ \\
\hline
\end{tabular}

Berdasarkan tabel 6 pekerjaan pengecatan mempunyai nilai cost slope terkecil sehingga pekerjaan pengecatan yang akan dilakukan crash.

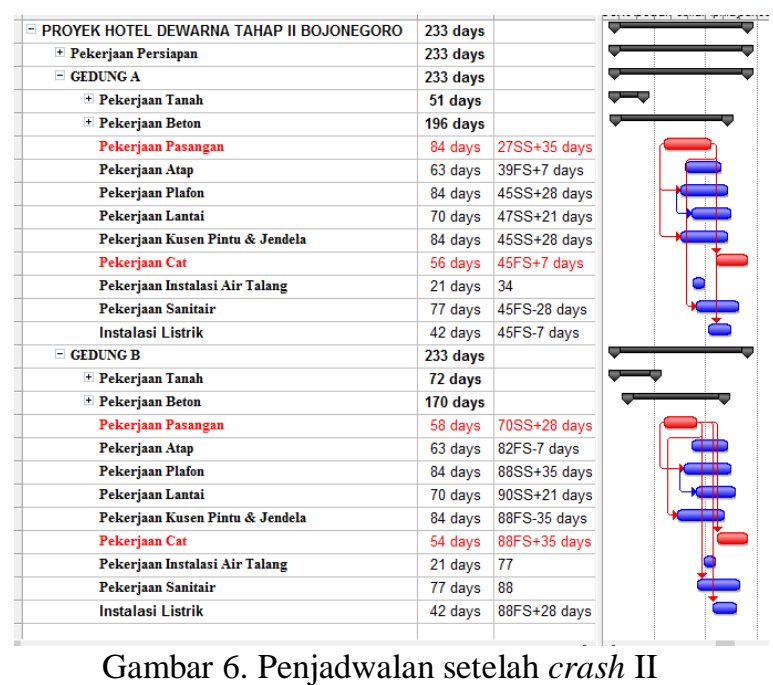

Karena crash dilakukan pada pekerjaan di gedung A dan B maka biaya yang dihitung adalah biaya langsung, biaya tidak langsung 
dan biaya tambahan dari masing-masing pekerjaan yang di crash.

Jadi biaya total akibat crash :

= Biaya langsung + biaya tidak langsung + biaya tambahan,

$=\mathrm{Rp} 23.025 .400 .563+\mathrm{Rp} 14.382 .146+(\mathrm{Rp}$ 15.428.078+Rp102.518.188 + Rp 9.759.931)

$=\operatorname{Rp} 26.504 .146 .817$

Perbandingan Penggunaan Metode FastTrack dan Crash Program

\section{Waktu}

Dari segi waktu penyelesaian proyek dengan menggunakan metode fast-track maupun dengan metode crash sama-sama membutuhkan waktu 233 hari.

\section{Biaya}

Dari segi biaya metode fast-track lebih murah dibandingkan dengan crash program hal ini karena pada metode fast-track tidak ada penambahan tenaga kerja maupun jam lembur, sedangkan metode crash menggunakan jam lembur sehingga ada penambahan biaya

Tabel 7 Perbandingan biaya

\begin{tabular}{cll}
\hline Sebelum & Metdoe Fast- & Metode \\
dipercepat $(\mathrm{Rp})$ & Track $(\mathrm{Rp})$ & Crash $(\mathrm{Rp})$ \\
\hline 27.059 .140 .712 & 26.376 .440 .619 & 26.504 .146 .817 \\
\hline
\end{tabular}

\section{Resiko}

Meskipun dari segi biaya metode fast-track lebih murah, namun resiko dari penerapan metode fast-track lebih besar yaitu pihak kontraktor harus menyediakan sumber daya yang cukup untuk pekerjaan-pekerjaan kritis yang akan dilakukan fast-track selain itu perlu dilakukan koordinasi secara rutin antar pihak selama proyek di lakukan fast-track agar tidak terjadi keterlambatan. Semakin banyak lintasan kritis yang dilakukan fast-track maka resikonya semakin besar apabila salah satu lintasan kritis terlambat akan berpengaruh pada lintasan kritis lainnya.

\section{KESIMPULAN DAN SARAN \\ Kesimpulan}

Berdasarkan hasil perhitungan kondisi saat ini diperoleh hasil sebagai berikut :

- Berdasarkan perhitungan percepatan waktu dan biaya dengan menggunakan metode fast-track diperoleh waktu penyelesaian proyek adalah 233 hari dengan biaya $\mathrm{Rp}$ 26.376.440.619, sedangkan perhitungan biaya sebelum dilakukan fast-track Rp 27.059.140.712.

- Sedangkan berdasarkan perhitungan percepatan waktu dan biaya dengan menggunakan metode crash program diperoleh waktu penyelesaian proyek adalah 233 hari dengan biaya $\mathrm{Rp}$ 26.504.146.817, sedangkan perhitungan biaya sebelum dilakukan crash program Rp 27.059.140.712.

- Dari perbandingan hasil dengan menggunakan metode fast-track dan crash program diketahui bahwa dari segi waktu sama-sama selesai dalam kurun waktu 233 hari, sedangkan dari segi biaya metode fast-track lebih murah dibandingkan dengan metode crash program. Namun metode fast-track memiliki resiko lebih besar karena apabila salah satu pekerjaan yang berada pada lintasan kritis terlambat akan mempengaruhi seluruh pekerjaan kritis lainnya.

\section{Saran}

- Perlu dilakukan penelitian pada proyek dengan kompleksitas yang lebih besar.

- Bagi penelitian selanjutnya melakukan perluasan penelitian dengan meneliti resiko-resiko akibat metode fast-track.

\section{DAFTAR PUSTAKA}

Barrie, Donald. S dan B. C. Paulson, jr. 1989. Profesional Construction Management, Mc Graw-Hill, Inc. New York.

Husen, Abrar. 2011. Manajemen Proyek. Andi. Yogyakarta.

James, S.C. 2012. Fast-Track Construction. (serial online), [cited 2013 May 6]. Available from

http://www.stevencjames.com/newsletter s/construction.

Khodijah Nyimas Syarifah, Sugandi Yahdin, Dan Novi Rustiana Dewi. 2013. Optimalisasi Pelaksanaan Proyek Pembangunan Persinyalan Elektrik di Stasiun Kertapati dengan Penerapan Metode Crash Program. Jurnal Penelitian Sains Universitas Sriwijaya Sumetera Selatan.

Mardianto, Dwi. Analisis Pengaruh Metode Fast-Track Pada Penjadwalan Terhadap Biaya Pelaksanaan Proyek Apartemen Parahyangan Residences. Tesis Insitut Teknologi Bandung. 
Soeharto, I. 1999. Manajemen Proyek dari Konseptual Sampai Operational. Erlangga. Jakarta.

Tjaturono dan Mochtar, Indrasurya B. 2008 : Pengembangan Metode Fast-Track untuk Mereduksi Waktu dan Biaya Pelaksanaan Proyek. (Studi Kasus: Rumah Menengah di Malang, Jawa Timur), Media Komunikasi Teknik Sipil. Wardani Niken. 2014. Evaluasi Pengendalian Pelaksanaan Konstruksi pada Proyek Civil Work (Studi Kasus : Proyek SBP SBI Invest SMK Negeri 1 Kediri) . Tesis Universitas Brawijaya Malang.

Wirawan, I Gusti Ketut dan Sudarsana I. K. 2015. Manajemen Risiko Pada Proyek Konstruksi Dengan Metode Fast Track Studi Kasus Proyek Qunci Villas Dan Putri Naga Komodo. Jurnal Spektran Vol 3, No.2. 